\title{
PEMBERIAN DOLOMIT PADA KULTUR DAPHNIA SPP. SISTEM DAILY FEEDING PADA POPULASI DAPHNIA SPP. DAN KESTABILAN KUALITAS AIR.
}

\section{DOLOMITE ADDED AT CULTURE OF DAPHNIA SPP. DAILY FEEDING SYSTEM AT DAPHNIA SPP. POPULATION AND WATER QUALITY STABILITY.}

\author{
A. Shofy Mubarak, Diah Trie Ridyaning Tias dan Laksmi Sulmartiwi \\ Fakultas Perikanan dan Kelautan Universitas Airlangga \\ Kampus C Mulyorejo - Surabaya, 60115 Telp. 031-5911451
}

\begin{abstract}
Daphnia spp. was potential source of live feed to be developed for larvae of freshwater fish. One of maximize culture technology was daily feeding system with rice bran solution. This system able to increase Daphnia spp. population. The problem of daily feeding culture technology was water quality stability, such as high $\mathrm{pH}$ fluctuation and high ammonia concentration. Water $\mathrm{pH}$ stability and decrease of ammonia concentration could be increased by dolomite added which function as stabilize $\mathrm{pH}$ buffer. The aim of this research found out the dolomite dose and culture period that able to increase population and stabilize of water quality. Experimental design was Completely Random Design with 4 replicates those were A control (0 mg/l), B (50 mg/l), C (100 mg/l), D (150 mg/l), E (200 mg/l) and F (250 mg/l). Parameter that measured were Daphnia spp. population and water quality, such as temperature, $\mathrm{pH}$, ammonia, dissolve oxygen and alkalinity. The data were examined using ANAVA(Analysis of Variance) to know treatment effect and be continued by Duncan Multiple Range with trust of degree 0,05. for water stability using descriptif methode. Result of analysis showed that high population for all treatment were held on $6^{\text {th }}, 7^{\text {th }}$ and $8^{\text {th }}$ day with the highest Daphnia spp. population was held on $8^{\text {th }}$ day by $\mathrm{F}$ treatment (250 mg/l) were 9900 Daphnia spp./l. Water quality data showed different between each treatment.
\end{abstract}

Key word : dolomite, Daphnia spp. culture, daily feeding, population, water quality.

\section{Pendahuluan}

Daphnia spp. merupakan sumber pakan alami yang potensial untuk dikembangkan bagi larva ikan. Optimalisasi teknologi kultur Daphnia spp. salah satunya adalah dengan teknik kultur sistem daily feeding, yaitu teknologi kultur Daphnia spp. yang memberikan pakan tiap hari dengan jumlah dan nutrisi yang cukup. Teknik kultur sistem daily feeding yang terbaik adalah menggunakan air rendaman dedak, sehingga Daphnia spp. tidak kekurangan pakan dalam kulturnya. Sistem daily feeding ini juga mampu meningkatkan populasi Daphnia spp. (Mubarak, 2007). Kendala teknologi kultur daily feeding yaitu pada kestabilan kualitas air di antaranya peningkatan konsentrasi amoniak yang dipengaruhi oleh sisa bahan organik yang menyebabkan rentang $\mathrm{pH}$ menjadi besar.

Kestabilan $\mathrm{pH}$ dalam media pemeliharaan Daphnia spp. dapat ditingkatkan dengan penambahan dolomit (Purwakusuma, 2007) yang berfungsi sebagai buffer (alkalinitas) karena mengikat $\mathrm{CO}_{2}$ menjadi bentuk $\mathrm{HCO}_{3}{ }^{2-}$ sehingga dapat menekan peningkatan konsentrasi amoniak. Apabila konsentrasi amoniak rendah maka $\mathrm{pH}$ juga cenderung stabil (Mahasri, 2004). Dolomit juga mempunyai fungsi sebagai sumber unsur $\mathrm{Ca}$ dan $\mathrm{Mg}$ yang sangat dibutuhkan untuk pembentukan carapace Daphnia spp.. Apabila kualitas air mendukung dan kebutuhan mineral yang dibutuhkan oleh Daphnia spp. tercukupi diharapkan jumlah populasi Daphnia spp. akan meningkat dan puncak populasi Daphnia spp. cenderung akan lama.

Tujuan dari penelitian ini adalah untuk mengetahui konsentrasi dolomit yang dapat meningkatkan populasi Daphnia spp. dan memperpanjang puncak populasi serta dapat menstabilkan kualitas air media pemeliharaan.

Manfaat penelitian ini adalah memberikan informasi ilmiah mengenai pengaruh dolomit dalam budidaya Daphnia spp. pada sistem daily feeding menggunakan air rendaman dedak sehingga akan menunjang usaha pembenihan ikan dalam penyediaan pakan alami.

\section{Materi dan Metode Penelitian}

Penelitian ini dilaksanakan pada tanggal 11-25 Desember 2007 di Laboratorium Pendidikan Perikanan, Fakultas Kedokteran Hewan, Universitas Airlangga Surabaya. 
Alat yang digunakan selama penelitian adalah bak plastik dengan diameter \pm $30 \mathrm{~cm}$ dan tinggi $19 \mathrm{~cm}$ sebanyak 20 buah, aerator dan selang aerator, wadah plastik 4 buah, gelas ukur $50 \mathrm{ml}$ dan $1000 \mathrm{ml}$, pipet, saringan, timbangan dan mortar. Alat untuk mengukur kualitas air adalah $\mathrm{pH}$ pen, pipet volumetrik dan bulb untuk mengukur oksigen terlarut, termometer, alkalinitas test kit dan amoniak test kit.

Bahan yang digunakan selama penelitian adalah bibit Daphnia spp. sebanyak 4800 ekor, dedak sebanyak 2,88 kg dan dolomit sebanyak $3000 \mathrm{mg}$.

Penelitian ini menggunakan metode eksperimen, yaitu suatu cara untuk mencari hubungan sebab akibat (hubungan kausal) antara dua faktor yang sengaja ditimbulkan oleh peneliti dengan mengeleminasi atau mengurangi serta menyisihkan faktor-faktor lain yang bisa mengganggu (Arikunto, 2002).

Berdasarkan penelitian pendahuluan, dosis dolomit yang optimal untuk pertumbuhan Daphnia spp. yaitu $200 \mathrm{mg} / \mathrm{l}$. Penelitian utama bertujuan untuk mengetahui dosis optimal dolomit terhadap populasi Daphnia spp. dan kualitas air.

Penelitian ini menggunakan Rancangan Acak Lengkap dengan memberikan 6 perlakuan dan 4 ulangan:

A : kontrol (tanpa penambahan dolomit).

B : penambahan dolomit $50 \mathrm{mg} / \mathrm{l}$.

C : penambahan dolomit $100 \mathrm{mg} / \mathrm{l}$.

$\mathrm{D}$ : penambahan dolomit $150 \mathrm{mg} / \mathrm{l}$.

E : penambahan dolomit $200 \mathrm{mg} / \mathrm{l}$.

$\mathrm{F}$ : penambahan dolomit $250 \mathrm{mg} / \mathrm{l}$.

Kultur Daphnia spp. diawali dengan mempersiapkan air sebagai media pemeliharaan sebanyak 10 liter. Dolomityang telah ditimbang, dihaluskan terlebih dahulu menggunakan mortar kemudian dimasukkan ke dalam media pemeliharaan sesuai dengan dosis perlakuan dan setelah itu diaerasi selama 3 hari. Setelah 3 hari, Daphnia spp. dimasukkan ke dalam bak dengan jumlah 20 ekor/l (Mubarak, 2007). Mulai hari ke-0 kultur Daphnia spp. diberi air rendaman dedak (konsentrasi 125 ppm) sebagai pakan.
Berdasarkan penelitian Suryaningsih (2006), dedak sebanyak 100 gram direndam dalam 500 $\mathrm{ml}$ air $(0,2$ gram/ml) selama 5 menit, kemudian diberikan pada Daphnia spp. dengan dosis 5 $\mathrm{ml} / \mathrm{l}$. Metode pemeliharaan dilakukan dengan sistem daily feeding yaitu teknik kultur yang memberikan pakan tiap hari.

Parameter yang diamati adalah jumlah populasi Daphnia spp., lama puncak populasi dan kualitas air yaitu $\mathrm{pH}$, amoniak, suhu, oksigen terlarut dan alkalinitas. Penghitungan populasi Daphnia spp. dengan cara mengambil media kultur Daphnia spp. dengan menggunakan pipa (diameter $1 \mathrm{~cm}$ ). Pipa dimasukkan ke dalam media pemeliharaan sampai ke dasar media dengan titik sampling ditentukan secara acak, kemudian dimasukkan ke dalam gelas ukur sebanyak $50 \quad \mathrm{ml}$. Kemudian, Daphnia spp. dihitung dengan bantuan pipet. Penghitungan diulangi sebanyak 3 kali. Menurut Suryaningsih (2006), perhitungan populasi Daphnia spp. pada bak dilakukan dengan rumus sebagai berikut :

Populasi keseluruhan $=$

populasi sampel (individu) x volume bak $(10000 \mathrm{ml})$ Volume sampel $(50 \mathrm{ml})$

Data penelitian yang diperoleh kemudian dianalisis menggunakan ANAVA (Analisis Varian) untuk mengetahui pengaruh dolomit terhadap populasi Daphnia spp.. Jika terdapat perbedaan di antara perlakuan maka dilanjutkan dengan Uji Jarak Berganda Duncan dengan derajat kepercayaan 0,05 untuk mengetahui perlakuan yang terbaik (Kusriningrum, 1989). Untuk kestabilan kualitas air dianalisis secara deskriptif.

\section{Hasil dan Pembahasan}

Populasi

Rata-rata populasi pada perlakuan A (tanpa dolomit) sebagai kontrol menunjukkan populasi yang rendah bila dibandingkan pada perlakuan pemberian dolomit pada media pemeliharaan. Populasi yang tertinggi pada perlakuan $\mathrm{F}$ dengan dosis dolomit paling tinggi $(250 \mathrm{mg} / \mathrm{l})$ kemudian diikuti oleh perlakuan E, $\mathrm{D}, \mathrm{C}$ dan $\mathrm{B}$. 


\section{Populasi Daphnia spp. per liter}

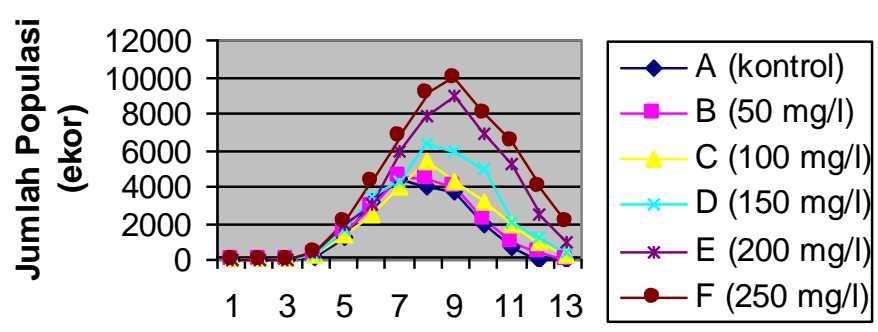

Pengamatan (Hari ke-)

Gambar 1. Grafik pertumbuhan populasi Daphnia spp. per liter
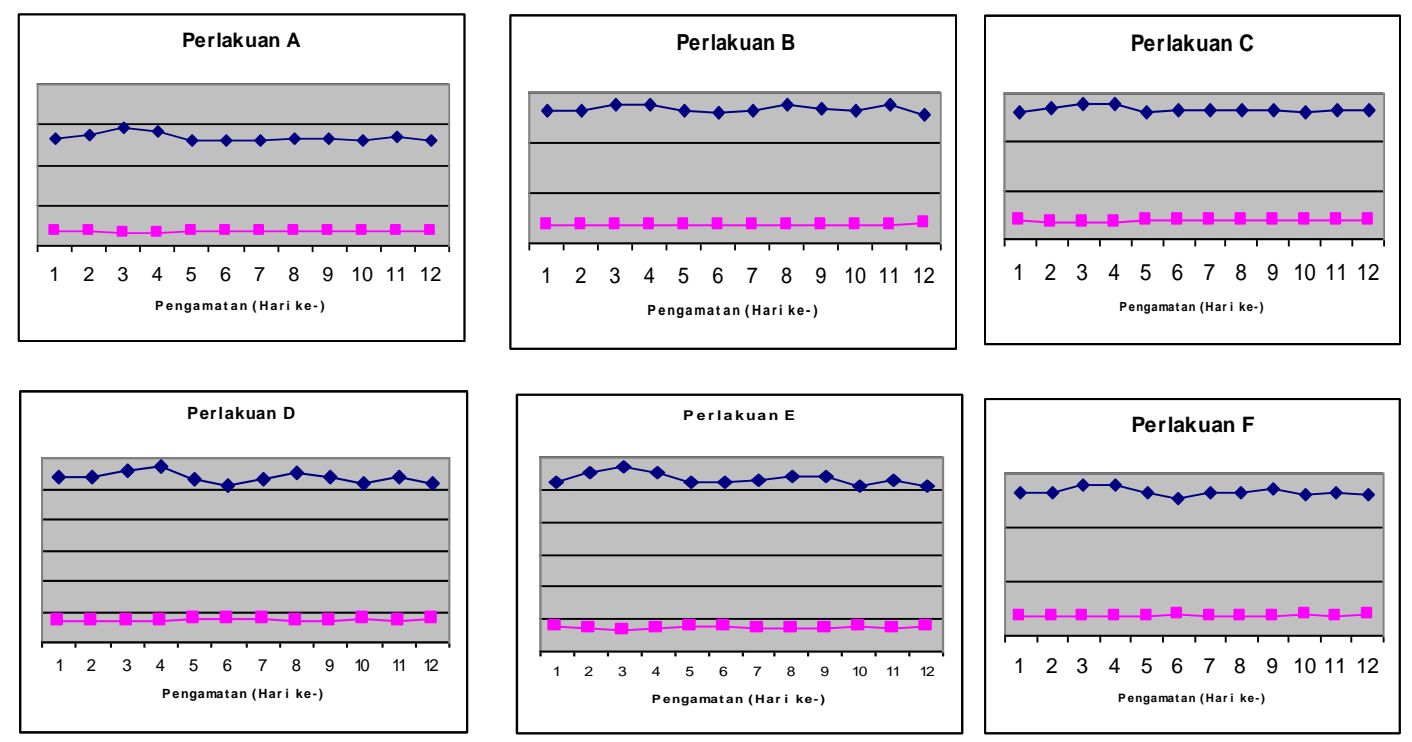

Gambar 2. Nilai rata-rata suhu dan oksigen terlarut pada tiap-tiap perlakuan

Keterangan : Biru $=$ Suhu $\left({ }^{\circ} \mathrm{C}\right)$

Merah muda $=$ Oksigen terlarut $(\mathrm{mg} / \mathrm{l})$

Puncak populasi Daphnia spp. terjadi pada hari ke-6 untuk perlakuan A (4380 ekor/l) dan perlakuan B (4600 ekor/l). Perlakuan C (5400 ekor/l) dan D (6320 ekor/l) puncak populasi terjadi pada hari ke-7, sedangkan untuk perlakuan E (8900 ekor/l) dan F (9900 ekor/l) puncak populasi terjadi pada hari ke-8. Hasil analisis statistik menunjukkan bahwa populasi Daphnia spp. pada hari ke-1 menunjukkan hasil yang tidak berbeda nyata di antara semua perlakuan ( $\mathrm{P}>0.05)$. Populasi Daphnia spp. menunjukkan hasil yang sangat berbeda nyata pada hari ke-4, ke-5, ke-7 sampai hari ke-11 untuk masing-masing perlakuan $(\mathrm{p}<0.05)$. Grafik populasi Daphnia spp. selama penelitian dapat dilihat pada Gambar 1.
Kualitas Air

Faktor kualitas air yang mempengaruhi daya dukung bagi Daphnia spp. adalah suhu, oksigen terlarut, $\mathrm{pH}$, amoniak dan alkalinitas. Rata-rata suhu dan oksigen terlarut pada tiaptiap perlakuan dapat dilihat pada Gambar 2.

Gambar 2. menunjukkan rata-rata suhu pada perlakuan A (kontrol) meningkat pada hari ke-3 dan ke-4 yaitu $29-30^{\circ} \mathrm{C}$ sehingga kadar oksigen terlarut menjadi turun yaitu 3,2-3 mg/l. Pada perlakuan pemberian dolomit yaitu perlakuan $\mathrm{B}, \mathrm{C}, \mathrm{D}, \mathrm{E}$ dan $\mathrm{F}$ juga mengalami peningkatan pada hari ke-3 dan ke-4 dengan kadar oksigen terlarut yang berkisar antara 3,2-4 $\mathrm{mg} / \mathrm{l}$. Nilai rata-rata $\mathrm{pH}$, amoniak dan alkalinitas pada tiap-tiap perlakuan dapat dilihat pada Gambar 3. 

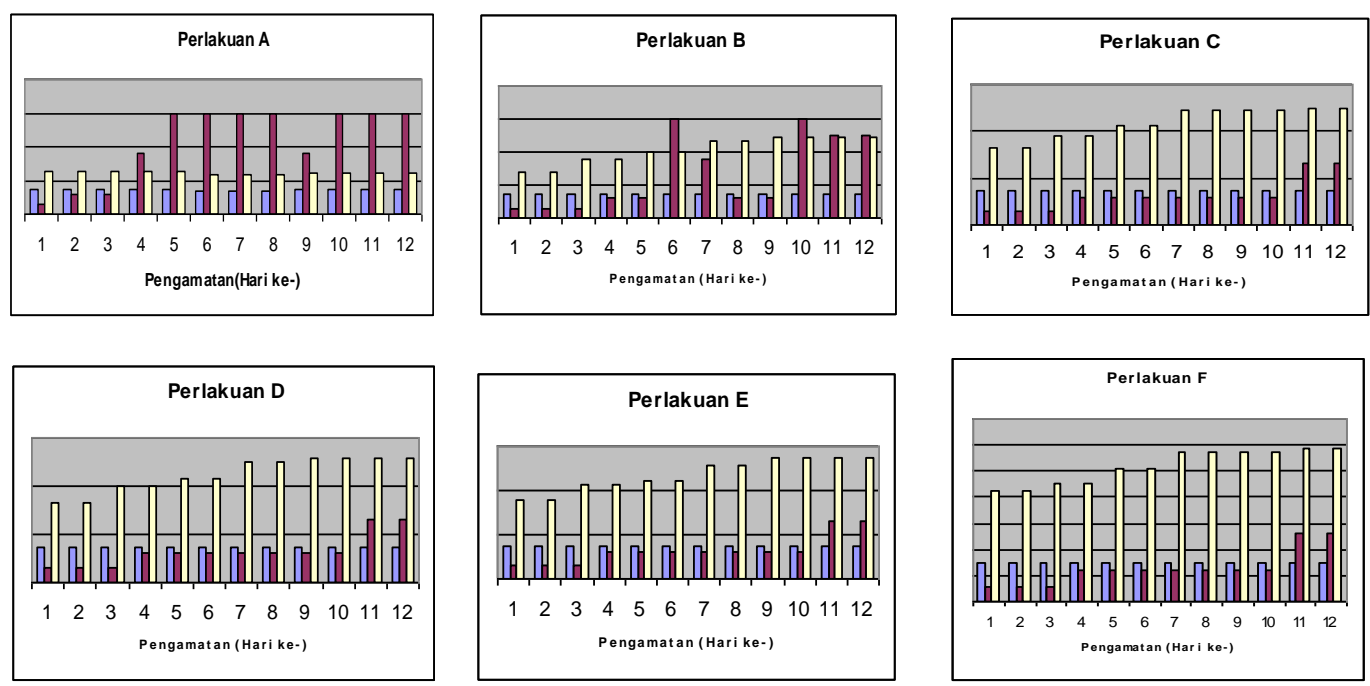

Gambar 3. Nilai rata-rata $\mathrm{pH}$, amoniak dan alkalinitas pada tiap-tiap perlakuan

Keterangan : $\mathrm{Biru}=\mathrm{pH}$

Merah = Amoniak $(\mathrm{mg} / \mathrm{l})$

Kuning $=$ Alkalinitas $(\mathrm{mg} / \mathrm{l})$

Gambar 3. menunjukkan rata-rata amoniak pada perlakuan A (kontrol) sangat berfluktuasi yaitu berkisar antara 0,003-0,03 mg/l, sedangkan nilai $\mathrm{pH}$ berkisar antara 6,6-7,2 dan alkalinitas berkisar antara 115,9-128,1 mg/l. Konsentrasi amoniak meningkat pada hari ke-3 sampai hari ke-7 diikuti dengan penurunan $\mathrm{pH}$ dan alkalinitas. Pada perlakuan pemberian dolomit yaitu perlakuan B, C, D, E dan F konsentrasi amoniak lebih stabil dan nilai $\mathrm{pH}$ juga stabil, sedangkan alkalinitasnya semakin hari semakin meningkat. Konsentrasi amoniak berkisar antara 0,003-0,02 mg/l. Nilai $\mathrm{pH}$ yang berkisar antara $7,1-7,5$ dan alkalinitas yang berkisar antara $140,3-274,5 \mathrm{mg} / \mathrm{l}$.

Lama Pencapaian Puncak Populasi dan Lama Puncak Populasi

Menurut Isnansetyo dan Kurniastuti (1995), lama pencapaian puncak populasi adalah waktu antara awal kultur sampai puncak populasi sedangkan lama puncak populasi adalah waktu yang dibutuhkan saat populasi berada di puncak atau kepadatan relatif konstan.

Pada perlakuan A sebagai kontrol pencapaian puncak populasi terjadi selama 6 hari. Lama puncak populasi hanya terjadi 1 hari dan pada hari ke-7 jumlah populasinya menurun. Perlakuan B dan C lama puncak populasinya terjadi selama 2 hari yaitu hari ke-6 dan ke-7 untuk perlakuan B dengan pencapaian puncak populasi terjadi selama 6 hari, sedangkan untuk perlakuan C lama puncak populasi terjadi pada hari ke-7 dan ke- 8 dengan pencapaian puncak populasi yang terjadi selama 7 hari. Perlakuan D pencapaian puncak populasi terjadi selama 7 hari dengan lama puncak populasi terjadi 4 hari yaitu hari ke-6 sampai ke9 dan pada hari ke-10 jumlah populasinya menurun. Perlakuan E dan F pencapaian puncak populasi terjadi selama 8 hari dengan lama puncak populasi untuk perlakuan E yaitu 5 hari mulai hari ke-6 sampai ke-10 dan pada hari ke11 jumlah populasi menurun, sedangkan pada perlakuan $\mathrm{F}$ puncak populasi terjadi selama 6 hari dari hari ke-5 sampai ke-10 tetapi sampai hari ke-12 populasinya tetap tinggi.

Semua perlakuan menunjukkan bahwa populasi Daphnia spp. pada awal kultur dan hari ke-1, jumlah populasinya belum mengalami penambahan karena masih dalam tahap adaptasi terhadap lingkungan kultur (Isnansetyo dan Kurniastuti, 1995). Setelah hari ke-2, populasi meningkat karena mulai terjadi partenogenesis yang menghasilkan anakan baru dengan cepat sampai mencapai puncak populasi. Salah satu faktor yang mempengaruhi populasi Daphnia spp. yaitu pakan. Melalui teknik kultur daily feeding menggunakan air rendaman dedak sebagai pakan (Mubarak, 2007) sehingga Daphnia spp. tidak sampai kekurangan pakan.

Pada perlakuan pemberian dolomit, jumlah individu yang dihasilkan lebih banyak. Dolomit sebagai sumber unsur $\mathrm{Ca}$ dan $\mathrm{Mg}$ dalam air dimana $\mathrm{Ca}$ berfungsi dalam pembentukan dan pemeliharaan struktur kerangka tubuh, sehingga ukuran tubuh dan kantung induk Daphnia spp. menjadi lebih besar yang berfungsi untuk menghasilkan individu baru (Hulsmann, 2000), sedangkan Mg 
berperan dalam metabolisme karbohidrat (Ichwan, 2003).

Faktor lain yang mempengaruhi populasi Daphnia spp. adalah kualitas air di antaranya adalah suhu, oksigen terlarut, $\mathrm{pH}$, amoniak dan alkalinitas (Penn State University, 2006). Menurut Suryaningsih (2006) pada hari ke-6 sampai ke-9 kultur Daphnia spp., pH sangat berfluktuasi diikuti dengan penurunan populasi Daphnia spp. secara drastis.

Suhu merupakan faktor abiotik yang mempengaruhi peningkatan dan penurunan aktivitas organisme seperti reproduksi, pertumbuhan dan kematian (Ananthakrishnan dan Viswanathan, 1983 dalam Suryaningsih, 2006). Di luar kisaran suhu optimum, Daphnia spp. cenderung dorman (tidak melakukan reproduksi) (Radini, 2006). Daphnia spp. hidup pada kisaran suhu $22-31^{\circ} \mathrm{C}$. Kisaran suhu tersebut merupakan kisaran suhu optimal bagi pertumbuhan dan perkembangan Daphnia spp (Radini, 2006). Selama penelitian, suhu yang diamati berkisar $25-30^{\circ} \mathrm{C}$ termasuk dalam kisaran Daphnia spp. tumbuh normal.

Oksigen terlarut merupakan faktor yang sangat penting dalam perairan, terutama untuk proses respirasi bagi sebagian organisme air (Ward, 1992 dalam Mone, 2007). Kelarutan oksigen dipengaruhi oleh suhu. Nilai suhu berbanding terbalik dengan konsentrasi oksigen terlarut. Semakin tinggi suhu maka kadar oksigen terlarut semakin rendah, begitupun sebaliknya (Wiadnya, 1994). Oksigen terlarut selama penelitian berkisar antara 3-4 $\mathrm{mg} / \mathrm{l}$, hal ini sesuai dengan Radini (2006) bahwa, konsentrasi oksigen terlarut yang optimal untuk kultur Daphnia spp. yaitu >3 mg/l. Oksigen terlarut dapat ditingkatkan melalui penggunaan aerasi dan bak pemeliharaan yang diletakkan di luar ruangan, sehingga sirkulasi oksigen dapat berjalan dengan baik, dari aerasi maupun difusi udara.

Perlakuan pemberian dolomit, $\mathrm{pH}$ selama pemeliharaan berada pada kisaran optimum pertumbuhan Daphnia spp., yaitu 7,17,5 hal ini karena nilai alkalinitas pada perlakuan pemberian dolomit meningkat selama periode kultur dibandingkan dengan kontrol yang cenderung menurun. Alkalinitas air bisa didefinisikan sebagai kapasitas air terhadap asam netral (Sentosa, 2007). Konsentrasi pH berbanding lurus dengan alkalinitas. Apabila alkalinitas meningkat, maka $\mathrm{pH}$ juga cenderung meningkat, begitupun sebaliknya (Wiadnya, 1994). Pada kontrol alkalinitasnya semakin hari semakin menurun dari 128,1 menjadi 115,9 $\mathrm{mg} / \mathrm{l}$, hal inilah yang menyebabkan daya sangga air terhadap $\mathrm{pH}$ menurun, sehingga $\mathrm{pH}$ pada hari ke-7 menurun tajam, diikuti populasinya pada hari ke-7 juga ikut menurun (deklinasi). Alkalinitas untuk perlakuan pemberian dolomit meningkat secara perlahan-lahan yaitu mulai 140,3 sampai $274,5 \mathrm{mg} / \mathrm{l}$, dikarenakan dolomit termasuk jenis kapur yang sulit larut dalam air, tetapi kelarutannya akan meningkat bila tersedia karbondioksida $\left(\mathrm{CO}_{2}\right)$.

Amoniak berasal dari dekomposisi bahan organik yang mengandung unsur nitrogen (Amstrong, 1995). Peningkatan konsentrasi amoniak akan menurunkan nilai $\mathrm{pH}$ sehingga rentang $\mathrm{pH}$ selama kultur menjadi besar, hal ini terjadi pada kontrol (tanpa dolomit) yaitu antara 6,6-7,2. Rentang $\mathrm{pH}$ dan amoniak yang besar tersebut dapat menurunkan reproduksi disebabkan $\mathrm{pH}$ tidak termasuk dalam kisaran optimum untuk pertumbuhan Daphnia spp. yaitu antara 7 sampai 8,5 (Radini, 2006), sehingga populasi Daphnia spp. menjadi stagnan atau turun. Di dalam air, perbandingan konsentrasi $\mathrm{NH}_{4}{ }^{+}$terhadap $\mathrm{NH}_{3}$ akan meningkat dengan menurunnya $\mathrm{pH}$ dan sebaliknya (Wiadnya, 1994). Kadar amoniak untuk kontrol selama penelitian berada pada kisaran 0,003$0,03 \mathrm{mg} / \mathrm{l}$, sedangkan pada perlakuan pemberian dolomit berkisar antara 0,003-0,02 mg/l, masih berada di kisaran amoniak yang aman untuk kultur Daphnia spp. yaitu di bawah $0,2 \mathrm{mg} / \mathrm{l}$ (Radini, 2006). Amoniak merupakan salah satu pemicu stres bagi Daphnia spp. yang dapat menyebabkan Daphnia spp. memproduksi telur yang nantinya menjadi Daphnia spp. berjenis kelamin jantan sehingga populasi Daphnia spp. menjadi turun karena reproduksi tidak terjadi secara partenogenesis.

Amoniak dalam media pemeliharaan berasal dari sisa hasil metabolisme di antaranya urine dan feses serta penumpukan pakan yang tidak termanfaatkan oleh Daphnia spp., yang menghasilkan karbondioksida $\left(\mathrm{CO}_{2}\right)$ sehingga menyebabkan rentang $\mathrm{pH}$ menjadi besar karena rendahnya sistem buffer (alkalinitas). Alkalinitas dapat ditingkatkan dengan pengapuran, di antaranya menggunakan dolomit (Mahasri, 2004). Dolomit dalam air dapat mengikat $\mathrm{CO}_{2}$ menjadi $\mathrm{HCO}_{3}$ yang berfungsi sebagai sistem penyangga (buffer) perubahan $\mathrm{pH}$.

Pakan dan kualitas air mempengaruhi lama puncak populasi (periode stasioner) yaitu fase dimana kepadatan relatif konstan. Lama puncak populasi (periode stasioner) pada kontrol hanya terjadi selama 1 hari yaitu pada hari ke-6 dengan kepadatan yang rendah dan pemberian pakan yang terus menerus tanpa adanya penyangga dalam air yang menyebabkan kualitas air khususnya amoniak menjadi naik 
dan $\mathrm{pH}$ menjadi turun sehingga puncak populasi tidak dapat bertahan lama. Pada perlakuan pemberian dolomit periode stasioner terjadi lebih lama yaitu 2-5 hari, dengan kepadatan yang cukup besar sehingga pemberian pakan yang terus menerus akan termanfaatkan. Sisa pakan dan hasil metabolisme Daphnia spp. menyebabkan amoniak meningkat, tetapi dengan penggunaan dolomit peningkatan amoniak dapat ditekan sehingga fase stasionernya dapat bertahan. Pada perlakuan F dengan dosis $250 \mathrm{mg} / \mathrm{l}$ fase stasioner yang terjadi selama 6 hari dengan jumlah populasi paling besar sehingga pemberian pakan yang terus menerus akan lebih termanfaatkan. Sisa pakan dan hasil metabolisme dapat dinetralisir oleh dolomit karena dolomit mampu menjadi penyangga atau buffer untuk amoniak dan $\mathrm{pH}$ dalam media pemeliharaan Daphnia spp. sehingga populasinya masih tinggi bahkan sampai pada akhir kultur yaitu hari ke-12.

\section{Kesimpulan}

Penambahan dolomit dapat meningkatkan populasi Daphnia spp. dan dapat memperpanjang puncak populasi serta dapat menstabilkan kualitas air media pemeliharaan, khususnya $\mathrm{pH}$ dan amoniak.

Penambahan dolomit dengan dosis 250 $\mathrm{mg} / \mathrm{l}$ merupakan dosis terbaik yang mampu meningkatkan populasi Daphnia spp. dan memperpanjang puncak populasi serta dapat menstabilkan kualitas air media pemeliharaan.

Agar para pembudidaya Daphnia spp. dapat mengaplikasikan dolomit pada media pemeliharaan Daphnia spp. agar kestabilan kualitas air media pemeliharaan dapat terjaga sehingga populasi yang dihasilkan dapat optimal.

\section{Daftar Pustaka}

Amstrong, F.B. 1995. Buku Ajar Biokimia Edisi Ketiga. Alih Bahasa: R. F Maulany. Penerbit Buku Kedokteran EGC. Jakarta. Hal 11-18.

Arikunto. 2002. Prosedur Penelitian Suatu Pendekatan Praktek. Penerbit Rineka Cipta. Jakarta. Hal 62-86.

Hulsmann, S. 2000. Population Dynamics of Daphnia galeata in the Biomanipulated Bautzen Reservoir. Life History Strategies Against Food Defficiency and Predation. Institut tur Hydrobiologie Technischi Universtat. Dresden.
Ichwan, W.M. 2003. Membuat Pakan Ayam Ras Pedaging. Agromedia Pustaka. Jakarta. Hal 9-39.

Isnansetyo, A dan Kurniastuti. 1995. Teknik Kultur Phytoplankton dan Zooplankton Pakan Alami untuk Pembenihan Organisme Laut. Penerbit Kanisius. Yogyakarta. Hal 72-73.

Kusriningrum. 1989. dasar - dasar Perancangan Percobaan dan Rancangan Acak Lengkap. Universitas Airlangga. Surabaya. Hal 56-103.

Mahasri. G. 2004. Diktat Kuliah Manajemen Kualitas Air. Program Studi Budidaya Perairan. Fakultas Kedokteran Hewan Universitas Airlangga. Surabaya.

Mone, A. 2007. Pengaruh Penambahan Air Rendaman Dedak Dengan Dosis Yang Berbeda Sebagai Pakan Daphnia spp. Terhadap Produksi Ephippia Daphnia spp.. Skripsi. Program Studi S-1 Budidaya Perairan. Universitas Airlangga. Surabaya.

Mubarak, A.S 2007. Berkala Ilmiah Perikanan Vol 2 No 1. Program Studi Budidaya Perairan. Universitas Airlangga. Surabaya. Maret 2007.

Penn State University. 2006. Environmental Inquiry-Bioassays using Daphnia. Dalam: www.ebiomedia.com. November 2007. 4 hal.

Purwakusuma, 2007. Daphnia sp. Media Informasi Ikan Hias. Jakarta. Dalam: www.o-fish.com. Agustus 2007.

Radini. D, 2006. optimasi Suhu, pH Serta Jenis Pakan Pada Kultur Daphnia sp. Sekolah Ilmu dan Teknologi Hayat. Bandung.

Sentosa, PT. Cipta Mulia. 2007. Kesadahan Air. Jakarta Utara dalam www. Google.com. November 2007.

Suryaningsih, H. 2006. Pengaruh Perbedaan Konsentrasi Rendaman dedak terhadap Populasi Daphnia sp. Skripsi. Program Studi S-1 Budidaya Perairan. Universitas Airlangga. Surabaya.

Wiadnya, D. Gede R. 1994. Bahan Kuliah Analisis Laboratorium Kualitas Air. Jurusan PTA. Fakultas Pasca Sarjana. Universitas Brawijaya. Malang. 